\title{
"BLESSED IS HE WHO CONSIDERS THE POOR" PERSPECTIVES FROM BOOK V IN THE PSALTER
}

\section{Georg Fischer S $\mathbf{J}^{1}$}

\author{
University of Innsbruck \\ Research associate, Department of Old Testament Studies \\ University of Pretoria \\ E-mail: georg.fischer@uibk.ac.at
}

(Received 16/05/2016; accepted 19/08/2016)

\begin{abstract}
The fifth book of the Psalter shows a notable increase in the attention given to the poor. Several psalms therein emphasize this topic and occupy specific positions, e.g., Pss 107, 109, 146, and 147. Dominant themes are hunger, justice, and the constant and all-embracing support that God gives, and which leads, towards the end of the Psalter, to a number of psalms dedicated to praise of God.
\end{abstract}

\section{INTRODUCTION}

The quotation used in the title stems from Ps 41:2. It is the first phrase of the last psalm in the first book of the Psalter, and is a fitting introduction to one of the primary themes of the fifth book, which shows, in a special way, God's dealings with the poor. Reading through the Psalter, one finds, towards the end, several ideas which have not been mentioned before and which demonstrate that God is the one who has the clearest perception of the poor and that he cares for them with great compassion.

A general theme such as "The Psalms and the poor" requires some preparatory remarks:

a) The Old Testament in general also mirrors the difficult social conditions of large groups within the society of Israel. The people of Israel differ from the rest of the ancient Near East, in that they display a major interest in and openness towards their situation, trying to seek solutions for this continuous "wound" in the

1 This article is based on a paper read at the Pro Psalm Conference at the University of Pretoria on 28 August 2014, as part of the collaboration with that institution. I am especially grateful to Dirk Human for the invitation and his friendliness, and thank Mrs Felicity Stephens for having corrected the English of this article. 
community. ${ }^{2}$ This comes to the fore in legal texts (Exod 21:2-3; 22:20-21; Deut 15:1-18, etc.), in narratives (cf. 2 Kings 4:38-44; Neh 5), in prophetic accusations (such as Amos 2:6-8; 5:10-11; Mic 3:1-3) as well as in Wisdom literature, in teaching (cf. Proverbs, Ben Sira), discussion (e.g., Job), and other genres which treat the topic. Here, the Psalter has a special role. In it, the theme of the poor is often related to God in a personal way. Those who pray often confess to being poor, express their confidence in God's help, and praise him for his salvation. In the Old Testament, this resembles a reprocessing of the experiences and ideas found in its other books, applying them to the individual and communal relationship with God.

b) The topic is also to be found in my own field of Old Testament and ancient Near Eastern studies. Archaeological discoveries in Egypt and in the countries of the Fertile Crescent prove the existence of palaces, splendid temples and other great buildings lying side by side with very poor habitations. Ancient Near Eastern legal texts and narratives testify to the existence of personae miserae, making it clear that misery, deprivation and penury are an "eternal problem" in this area, going back at least as far as the earliest records discovered to date.

c) My experiences in slums in poor Asian countries brought home to me the reality of poverty as an actual and pressing problem on a worldwide scale, involving more than half of the population on earth. I imagine that the situation in South Africa, for the majority of its people, is quite similar. ${ }^{3}$ Despite all international efforts and declared intentions, the gap between rich and poor in the world has not diminished; on the contrary, it continues to increase every year.

2 Writing the books of the Hebrew Bible is a sign of high erudition, in all likelihood only to be found in scribes/priests/individuals belonging to the "upper class" of Israelite society. It is all the more astonishing that they show such an empathy with and continuous interest in the concerns of the poor; cf. Premstaller (2007:480-493, esp. 481): ,aus der Perspektive begüterter freier Menschen." For the difference to the ancient Near East see also Lohfink (1990:111): "Unterschied zum Armenethos des alten Orients".

3 Cf. Deist (1996:2-6). For my personal background, see the publications at the end of the bibliography. 
In the following, I will first run through Book V of the Psalms, sifting out the relevant passages. The list gives an overview ${ }^{4}$ of the pertinent texts in the sequence in which they appear in Psalms 107-150, as the order in which they occur is deliberately arranged, and thus testifies to a desire to communicate the message in this particular way. Then I will evaluate the main findings, and finally pose some questions and draw a few conclusions.

\section{AN OVERVIEW OF SOME MAJOR TEXTS FOR THE THEME OF THE "POOR" IN PSALMS 107-150}

\section{Psalm 107}

There is some debate about whether or not Ps 107 is to be taken as the beginning of the fifth book of the Psalms, as it displays very close connections with the two preceding psalms, 105 and 106 (Ballhorn 2004:134-135). In the latter, the motifs of "remembering" (זכר) and God's "wonders" (פלא (זר) are used very often (thrice and twice respectively, in each psalm) and thus prepare the reader for Ps 107 in which "and his wonders" (ונפלאותיו) occurs five times in vv. 8, 15, 21, 24 and 31. This is the greatest density of occurrences of this root to be found in the whole of the Hebrew Bible and thus bringing the motif to a climax here.

Although dealing also with "history" like the previous psalms, Ps 107 nevertheless reflects a changed perspective whereby the focus is now on individuals and their suffering. Psalm 107 can thus be seen as a transition and a beginning, making it a suitable opening for a new "book".

Psalm 107 is also very special in that it mentions several forms of "poverty" and need. ${ }^{5}$ It starts right away in v. 2 with those "redeemed ${ }^{6}$ by Yhwh ... from the hand of (the?) ${ }^{\prime \prime}{ }^{7}$

4 The article by Bremer (2013:55-84) was helpful for the original presentation in 2014. In the first part, he gives an outline of the terminology regarding the poor in the whole Psalter; the second part, from p. 68 onwards, focusses on the fifth book of the Psalter specifically. Meanwhile, his thesis on this topic has been published (Bremer 2016).

5 Normally studies on the poor concentrate on the specific terms for them, like על ,אביון, עני, and the other roots and words. However, "poverty" is not restricted to the passages where 
Verse 4 speaks of returnees wandering in the desert, failing to find their way to an inhabited city, a problem which is resolved in v. 7.

Verse 5 mentions their hunger and thirst, being satiated by God in v. 6 and generalised in v. 9.

Verse 10 introduces a new theme with "prisoners in affliction and in irons;", once again God comes to their aid (vv. 13-14).

The following verses continue to enumerate various forms of trouble: fools at the gates of death, vv. 17-18; danger to those at sea, vv. 23-27 (-32). They also revisit earlier topics, e.g., "the hungry" in v. $36 .{ }^{9}$

Verses 40-41 are a form of summing up. The dynamic of divine interventions reaches its highpoint (Fischer 2012:238) in bringing down the nobles, and elevating the poor/needy (אביון), "lifted up from their affliction".

The end in vv. 42-43 invites the just ones to rejoice and makes a final request for every wise person to "keep" (שמר) and "reflect (בין hitp.) on the loyal deeds of Yhwh".

Ps 107 opens the fifth book of the Psalter and seems to be a sort of introduction to it. Its main theme is how God intervenes miraculously to help those in need, particularly the poor and those in trouble, showing them his grace and reversing their misfortunes.

\section{Psalm 109}

Psalm 109:16 accuses a wicked man of having "pursued the poor and needy and the

explicit expressions for it show up; it comes to the fore in concrete experiences of starving, deficiency, etc. Therefore the investigation has to be wider and include also the references to other forms of deprivation and need.

6 This verse uses גאל twice.

7 Most of the following translations are from the NRSV, unless otherwise indicated. Here it renders with "trouble", but "oppressor" might fit better; cf. Ps 108:13.

8 Psalm 116:16 mentions God's "loosing bonds" (of a servant).

9 The repetition of "hunger" emphasises this need. The motif will recur several times in this fifth book, and it was already prominent before; see Ps 22:27 and Barbiero (2002:168-184). For the interpretation of the "fools" mentioned in Ps 107:17 see note 20.

10 "Affliction" renders the root ענ, as in v. 10; "their" is not present in the Hebrew text. Here in v. 41 both main terms for "poor/poverty" are used together, as also in Ps 109:16, 22 and 140:13. Bremer's title of his article (Bremer 2013; see note 4) is taken from this verse. 
broken-hearted to their death". A few verses later (v. 22) the psalmist declares himself to be such a person: "For I am poor and needy, and my heart is stricken within me". The final verse, v. 31, affirms confidently about God: "For he stands at the right hand of the needy, to save him from those who condemn him to death". 11

The second part of Ps 109 is clearly dominated by the theme of the poor. Cruelty towards the poor and needy is the accusation made against the evildoer (v. 16). The prayer identifies himself as being poor in v. 22 with the same two words עני ואביון as in v. 16, thus emphasising it. ${ }^{12}$ This double expression picks up Deut 15:11 and 24:14; in the Psalms it occurs more often, the first occurrences being in Pss 37:14 and 40:18. The psalm ends with a general statement about God's attitude, namely, that he stands in solidarity with those in need and rescues them from oppressors.

\section{Psalm 112}

Psalm 112 presents the ideal of one who fears Yhwh. An essential feature of such a one is "He has distributed freely, he has given to the poor". Verse 9 employs the plural and applies a divine characteristic to the righteous, God-fearing person. ${ }^{13}$ The blessing at the beginning in v. 1 may be connected with the blessing of our title, taken from Ps 41:2; Ps 112:9 may be seen as one realisation of it.

\section{Psalm 113}

Psalm 113 introduces, in vv. 7-8, a quote from 1 Sam 2:8, thus highlighting the importance of Hannah's prayer and its orientation, and a variation on the motif of Ps 107:40-41: "He raises the poor (דל) from the dust, and lifts the needy from the ash heap, to make them sit with nobles ..." The translation "ash heap" for is weak;

11 The last words of v. 31 are open to various interpretations; see Zenger (2008:192). Literally this last stich says: "to save from (those) judging his soul/person". Ulrich Berges (2004) has taken the beginning of v. 31 as the title for his article: "God staat aan de kant van de armen" (Ps. 109,31). Armoede en rijkdom in het psalmenboek.

12 Gillingham (1988:15-19, here 17) interprets the double designation as denoting people "deprived of their rights".

13 Ballhorn (2004:164): “Anwendung der Gottesprädikate auf den Gerechten”. 
literally, the Hebrew word indicates a heap of ashes, dung and refuse. ${ }^{14}$ The use of the term דל "low one," and after God's intervention.

The final verse, v. 9, changes the fate of the barren woman, thus achieving a balance between the genders with respect to divine help. ${ }^{16}$

Pierre Coulange ${ }^{17}$ has elaborated extensively on the theological background of these changes of fortune and hierarchies in society. God's cosmic transcendence stands at the centre of Ps 113, in vv. 4-6; nevertheless, he is "infiniment proche" and combines "hauteur et bassesse". ${ }^{18}$ The question "Who is like Yhwh, our God?" in the epicentre in v. 5, receives its answer in his dealings with the lowly ones in vv. 7-9: Indeed, who does take care of those often despised individuals and groups? ${ }^{19}$

Psalm 113, despite its brevity, or maybe even because of it, relates changes of poor people's sufferings to the biblical God's unique character in the clearest way. Thus it invites, even impels, the reader to look at other occasions when their misery was relieved in connection with God and his predilection for them.

Then there is a long gap in instances of designations for the poor; however, Ps 116:6, and also Ps 142:7, use דלותי "I am/was brought low”. Psalm 116:6a mentions, even before the lowliness of the prayer, God keeping/protecting פתאים "the simple".

14 HALAT 1967:93; Fischer and Markl (2007:459-479, esp. 477). This evokes the millions of people searching through tons of waste to collect things which they can sell to live on.

15 Bremer (2013:72) situates the דל still below those designated by the two other, more frequent terms אביון and (1988:16) sees in the dallîm those "who lack physical means".

16 Ballhorn (2004:175): "Der Merismus setzt sich dann fort, indem dem männlichen Armen die weibliche Unfruchtbare an die Seite gestellt wird". Psalm 113:9, too, might have been influenced by Hannah's song of praise in 1 Sam 2 (esp. v. 5), but the match is not as precise as with the two verses before.

17 Coulange (2007). The entire first part of his monograph (2007:23-83) deals with Ps 113 .

18 Coulange (2007:52, 82). In English: "infinitely near", and "haughtiness and lowliness /servility".

19 Cortese (1993:1-23) distinguishes three different forms of the elevation of the poor; Ps 113 belongs to the first type, lifting him/them up to the level of the rich.

20 Cf. also אוילים "foolish, silly” in Ps 107:17; NRSV follows the proposed emendation of the text and translates "Some were sick ..." Psalm 107 thus explicitly includes in God's care even those who, because of their sins, go astray and have to suffer. 
Other occurrences for being "poor" or in need are found in Ps $119 .{ }^{21}$

\section{Psalm 132}

It is Ps 132:15 which speaks again of the poor. God promises Zion, addressed as a female: "I will satisfy her poor with bread".

Once again, as in Ps 107, there is an issue about getting enough food. ${ }^{22}$ For God feeding those who are hungry see also Ps 111:5 and Ps 136:25. Psalm 136:23 has in addition the unique expression שבשפלנו "who in our lowliness (remembered us)" which underlines God's care for those of low estate and is a key to the understanding of this psalm about God's ever-enduring

\section{Psalm 140}

Psalm 140 describes, in v. 12 (verse numbering follows the Hebrew), experiences with violent men and slanderers; v. 13, the second last verse of this psalm, expresses the conviction:

I know that Yhwh maintains the cause of the afflicted (דין עני), and executes justice for the needy (משפט אביונים).

Verse 14 describes the reaction, with the praise of God by the righteous. Both main roots for "poor" are present here (cf. also Pss 107; 109 above). Divine support linked to judicial procedures. The phrase דין עני has two further occurrences, in Jer 22:16 and in Prov 31:9. Legal assistance by God for the poor may be indicated in Ps 109:31, too, and other passages, e.g., the "Armenpsalm" Ps 9 (see vv. 5, 9 there). Yhwh as judge of/for the poor will occur again in Ps 146:7.

21 Bremer (2013:74) lists vv. 50, 67, 75, 92, 107, 138, and 153 for uses of the root ענה IV. [v. 138 cannot be correct]. Verses 50, 92, and 153 show the same form, עניי "my affliction". He also refers to the "sojourner/stranger" in v. 19; with the exception of Ps 146:9 (see there) I do not deal further with this special group.

22 Ballhorn (2004:241) interprets: “... daß die Armen an der Fülle der Heilszeit ihren Anteil erhalten". Cf. also note 9 and Ps 146:7.

23 See especially Human (2004:83). 


\section{Psalm 145}

The last psalm attributed to David introduces new motifs for our theme in v. 14: "Yhwh upholds all who are falling, and raises up all who are bowed down".

These two groups are mentioned here for the first time, and the latter group (כפופים) is only mentioned once again in the Bible, namely in the immediately following Ps 146:8. The repeated "all" emphasises that nobody is excluded. The following vv. 15-16 vary and expand Ps 104:27-28. God satiates with food every living being, thus going even further than his promise in Ps 132:15, where bread was promised specifically to Zion.

Psalm 145 does not contain any of the classical terms for those being poor or in need. ${ }^{24}$ However, it describes God's attention and help for those groups who are "falling" and "bowed down", thus forming an exclusive link with Ps 146, generally understood to be concerned with the poor, and connecting the "Schluss-Hallel" (Pss 146-150) to the preceding last psalm of David. ${ }^{25}$

\section{Psalm 146}

The first Psalm of the final set of praise psalms offers in vv. 7-9 a kind of summary of God's interventions for various forms of "poor" people, once again without using the classical terms, as in Ps 145:

(v. 7) ... who executes justice for the oppressed; who gives food to the hungry.

Yhwh sets the prisoners free.

(v. 8) Yhwh opens the eyes of the blind. Yhwh lifts up those who are bowed down;

Yhwh loves the righteous.

24 This may be the reason why Bremer does not mention it. Yet, it is similar in Ps 146. There we do not find any of the usual words for "poor", but a number of specific groups belonging to them. As indicated above (note 5), this is a further hint not to restrict studies on poverty merely to a neatly defined vocabulary. Hossfeld (2008:800), too, discerns here the presence of "Armentheologie".

25 Zenger (1996:97-116, English translation 1998:77-102) has underlined the strong relationship between both psalms, and similarly also Ballhorn (2004:304-305). 
(v. 9) Yhwh watches over the sojourners / strangers, he upholds the orphan and the widow ...

Three times we find three groups of people in need or in situations of suffering; this may indicate completeness. The first phrase, where the "oppressed" (עשוקים) receive right judgment, draws on Ps 103:6 and introduces God's concrete interventions on the "earth" mentioned before in v. 6 .

The longest list of "poor" ones comprises many more groups than have been talked about before. A group of handicapped people ("blind") is new, and also the "Trias der sozial Schwachen", namely "sojourner, orphan, widow", known from Exod 22:21-22 and especially from the legislation in Deuteronomy (e.g., Deut 14:29). Therefore Ps 146 may be regarded as the culmination of our topic so far as it occurs in the Psalter. As in Ps 145, here, too, God's actions are connected with his kingship (Ps 146:10; Ps 145:1, 11-13).

\section{Psalm 147}

Psalm 147:2-3 adds further groups of "poor", namely the "dispersed"26 and two kinds of sick people, designated as "broken-hearted" ${ }^{27}$ and with "wounds". Verse 6 is still more specific, introducing, for the first time in our texts, the plural "ענוים "Yhwh lifts up the poor/lowly, he casts the wicked to the ground". Psalm 147 contrasts the poor with the רשיקים "wighteous". This indicates a tendency to connect the "poor" with other, differently designated groups. $^{30}$

26 NRSV translates as "outcasts", thus pointing in another direction.

27 Psalms 34:19 and 51:19 have a very similar expression.

28 It occurs 12 times in the Psalms, out of 21 times in the Old Testament. NRSV renders with "downtrodden".

29 See, for example, Ps 1. Bremer (2013:73) concludes that the poor “... treten damit an die Stelle der צדיקים (Gerechten)".

30 Hermann (1999:68-77) suggests the identification of the poor with those seeking (דרש) Yhwh. 


\section{Psalm 149}

The plural ענוים occurs once again in Ps 149:4: "For Yhwh takes pleasure in his people; he adorns the humble with victory/salvation". The parallelism allows us to link the poor/humble here with "his people", to be identified with Israel ${ }^{31}$ and also with the "assembly of the חסידים (faithful)", mentioned in v. 1, and similarly in vv. 5 and 9.

\section{EVALUATION}

From the texts seen above we may affirm several points:

1) The vocabulary used is quite diverse and indicates numerous different groups of "poor" people, thus recognising a "complex variety of life settings". ${ }^{32}$ Poverty is not limited to some particular aspects of reality, but is to be found in many groups, both genders, and in a great variety of situations. Thus any investigation of this topic should not limit itself to a narrow spectrum of terms (cf. note 6 above), but should include the whole range of terminology used to describe forms of deprivation and need presented. The use of so many expressions and designations relating to the poor may also suggest a variety of authors for these psalms, each using language specific to himself to express his particular experiences and concerns.

2) The so-called "Armenfrömmigkeit" is present, but it is neither all-pervading nor dominant. There is no single psalm completely informed by this theme. At most, only 13 (out of 44) psalms deal with this issue, and out of the thirteen only four, namely Pss 107, 109, 146, and 147 contain three or more verses dedicated to the poor. Therefore one should be cautious of seeing a group of poor people as being

31 So Ballhorn (2004:333): "Israel wird als Kollektiv mit der theologischen Größe der Armen identifiziert". Lohfink (1990:114) finds such identification already present in Ps 146.

32 Gillingham (1998:16). Tucker (2014) suggests Persian imperial ideology as background for the creation of these psalms; however, the implicit critique of imperial power might also apply to later times. 
responsible for the formation of these psalms ${ }^{33}$ - at least for the fifth book of the Psalms this seems inadequate.

3) The most important aspect is God's constant and all-encompassing assistance for all sorts of "poor": "They have God at their side". ${ }^{44}$ In all these psalms, divine help is always present, and those praying are confident of receiving it. Regarding the overall movement in the Psalms, there is an increase in God's support for the poor, with a clear dynamic from his perception of their suffering to an active involvement in effecting change for the better (Bremer 2013:62-63).

4) There is a significant difference between the fourth and the fifth book of the Psalms with regard to our topic. Psalms 90-106 contain only one explicit mention of "poor", ${ }^{35}$ concentrate on Yhwh as "king" of the universe (Pss 93-99) and conclude with two contrasting presentations on Israel's past history. Many Psalms of the fifth book, however, focus much more on individuals in misery and need, starting with Ps 107 as a fitting introduction to the book, and they also use the classical terms for "poor" ${ }^{36}$ This raises the question of the reasons/sources for such a difference.

5) The psalms containing more verses dealing with the poor have special positions. Psalm 107 (with 109) opens the fifth book, Pss 146-147 start the last collection of hymns. All these psalms stand in close relationship to groups of praise psalms

33 Also Croft (1987) points out the preponderance of individuals for our topic; see his Chapter 2, and especially the diagram on p.70.

34 So McPolin (1989:79-103, here 80). Bremer (2013:62, 66) emphasises the significant increase of divine salvific actions towards the end of the Psalter, and links it with the more frequent use of the term אביון;

35 In Ps 102:1 once עני; there are no other specific terms to be found.

36 An inventory of the main/classical vocabulary: אביון Pss 107:41; 109:16, 22, 31; 112:9; 132:15; 140:13; the last three occurrences are in the plural; עניוו Pss 109:16, 22; 140:13; in the plural ענוים Pss 147:6; 149:4; and also the דל Ps 113:7. There are further groups/texts that might be connected with "poor", e.g., the foreigners (as own experience in Ps 119:19, see above note 21; as threat in Ps 144:7; as group in need of protection Ps 146:9), the semantic field of oppression/oppressors (Ps 107:2; often in Ps 119, etc.), the suffering connected with being attacked, pushed (Ps 118:10-13), the references to the exile (for example, Ps 126), the term "lowliness" (שפל) in Ps 136:23, and all forms of injustice, social imbalance, etc. 
following. ${ }^{37}$ In key positions at the beginning of the respective collections, they lay the foundations for what follows, and they establish the different mode/tone of the fifth book.

6) Some motifs are repeated and thus obviously indicate long-term or frequentlyoccurring problems or sorrows. Among them, the issue of hunger is dominant (see Pss 107 through 146). Another emphasis lies on the receiving of justice (Pss $109: 31 ; 140: 13 ; 146: 7){ }^{38}$ This is something which has not changed up to now.

7) One can also observe that earlier passages and expressions are taken up - see the links with earlier texts in Pss 109; 113; 145 and 146. This points to further elaboration of important themes, combining them sometimes into a kind of anthology.

\section{QUESTIONS AND CONCLUSIONS}

a) Is Yhwh not concerned about poverty, but merely about poor people? ${ }^{39}$ In my view, the aspect of "justice" (see above) and the message of the prophets speak against it.

b) "It is only because the Bible considers material poverty as an evil that the book of Psalms has been able to reinterpret the vocabulary of poverty to speak about the oppression of the pious." Is this statement (Hoppe 2004:130) true? In the eyes of others, a dichotomy between the physical and spiritual dimension is not adequate. $^{40}$

c) How can one explain the notable difference of the fifth book of the Psalms?

d) There is a clear dynamic towards praising God in the single Psalms as well as in the overall movement of the Psalter. Divine help should lead to giving him thanks and rejoicing over him.

37 Psalms 111-113 are the second "Halleluja-Triade", following the fourth "Davidpsalter" (108-110); Pss 146-150 form the "Schluss-Hallel".

38 McPolin (1998:90-92) stresses this aspect.

39 Bremer (2013:59-60) holds this position.

40 For example, Gillingham (1988:18-19); Bremer (2013:64, 68). 
e) The psalms do not stay simply on the level of worship; they invite and encourage the imitation of God's support for the poor. ${ }^{41}$ How God is and acts, becomes a program and a motivation for his faithful. This is all the more necessary, as "the poor will never cease out of the land" (Deut 15:11).

f) God's constant support for the poor is deeply impressive as portrayed in these psalms. The confidence of the pious, who show a "strong spirit of trust in and dependence on God", ${ }^{42}$ is equally remarkable. It is possible that the inner attitude of people who experience great difficulties and suffering in their lives may make them well-disposed to receive God's attention and help. ${ }^{43}$

\section{BIBLIOGRAPHY}

Ballhorn, E 2004. Zum Telos des Psalters. Der Textzusammenhang des Vierten und Fünften Psalmenbuches (Ps 90-150). BBB 138. Berlin: Philo.

Barbiero, G 2002a. Die Eucharistie der 'anawim: Ps 22,23-32," in Barbiero 2002b:168-184. 2002. Studien zu alttestamentlichen Texten. SBAB 34. Stuttgart: PUBLISHER.

Berges, U 2004. „God staat aan de kant van de armen“(Ps. 109,31). Armoede en rijkdom in het psalmenboek, Tijdschrift voor Theologie 44:108-123.

Blomberg, C L 1999. Neither poverty nor riches. A biblical theology of material possessions, New Studies in Biblical Theology 7. Leicester: Inter Varsity Press.

Bosman, H L, Gous, I G P, and Spangenberg, I (eds) 1996. Plutocrats and paupers. Wealth and poverty in the Old Testament. Third edition. Pretoria: Van Schaik.

Bremer, J 2013. „Doch den עביון hob er aus dem עני empor.“ (Ps 107,41a) Eine synchrone Analyse des Umgangs Gottes mit den Armen im Psalter und diachrone Verortung im 5. Psalterbuch (Ps 107-145) und im Schluss-Hallel (Ps 146-150) Frank-Lothar Hossfeld zur Vollendung des 70. Lebensjahres, Biblische Notizen 158:55-84.

2016. Wo Gott sich auf die Armen einlässt. Der sozio-ökonomische Hintergrund der achämenidischen Provinz Yəhūd und seine Implikationen für die Armentheologie des Psalters. BBB 174. Göttingen: Vandenhoeck \& Ruprecht.

Cortese, E 1998. Dio innalza il povero: dai Salmi al Magnificat, Antonianum 68:1-23.

Coulange, P 2007. Dieu, ami des pauvres. Etude sur la connivence entre le Très-Haut et les petits. OBO 223. Fribourg: Universitätsverlag.

Croft, S J L 1987. The identity of the individual in the psalms. JSOTS 44. Sheffield: Sheffield

41 See the blessings in Pss 41:2 and 112:(1), 9 on the background of divine acting in favour of the poor, and further Premstaller (2007:487-490).

42 McPolin (1998:94) with regard to Ps 109.

43 The topic presented here belongs to my personal concerns and interests: the concept of Jesus as a "friend of the poor" has strongly influenced my vocation and my life, and since the early years of my professional life, has also informed my publications (see at the end of the bibliography). 
Academic Press.

Deist, F 1996. Wealth and poverty in South Africa, in Bosman, Gous \& Spangenberg1996:2-6.

Fischer, G 2012. Theologien des Alten Testaments. NSK-AT 31. Stuttgart: Katholisches

Bibelwerk.

Fischer, G, Markl, D 2007 . Armut als globale Herausforderung. Impulse aus der Sicht des

Alten Testaments, Zeitschrift für Katholische Theologie 129:459-479.

Gillingham, S 1988. The poor in the Psalms, Expository Times 100:15-19.

Herrmann, W 1999. Die Armen, die Gott suchen, in Kähler, Böhm \& Böttrich 1999:68-77.

Hoppe, L J 2004. There shall be no poor among you. Poverty in the Bible, Nashville: Abingdon Press.

Hossfeld, F-L, Zenger, E 2008. Psalmen 101-150. HthkAT. Freiburg: Herder.

Human, D J 2004. Psalm 136: a liturgy with reference to creation, in Human and Vos 2004:7388.

Human, D J and Vos, C J A (eds) 2004. Psalms and liturgy. JSOTS 410. London: T\&T Clark.

Kähler, C, Böhm, M \& Böttrich, C (eds) 1999. Gedenkt an das Wort. Festschrift für Werner Vogler zum 65. Geburtstag. Leipzig: Evangelischer Verlag.

Koehler, L and Baumgartner, W 1967. Hebräisches und Aramäisches Lexikon zum Alten Testament. Vol. 1. Leiden: Brill.

Lohfink, N 1990. Lobgesänge der Armen. Studien zum Magnifikat, den Hodajot von Qumran und einigen späten Psalmen. Stuttgarter Bibelstudien 143. Stuttgart: Katholisches Bibelwerk.

McPolin, J 1989. Psalms as prayers of the poor," in Cathcart and Ryan 1989:79-103.

Premstaller, V 2007. „Nimm dich des Bedürftigen an!“( Sir 29,9). Weisheitliche Lehren zur Armut, Zeitschrift für Katholische Theologie 129:480-493.

Tucker, D W Jr 2014. Constructing and deconstructing power in Psalms 107-150. Ancient Israel and Its Literature 19. Atlanta: SBL.

Zenger, E 1996. Komposition und Theologie des 5. Psalmenbuchs 107-145, Biblische Notizen 82:97-116 (English translation: JSOT 80 (1998), pp. 77-102).

\section{Early publications by the author}

1980. Erfahrungen in einer städtischen Sozialwohnung, Entschlu $\beta$ 6:18.

1993-1994. Four "Letters to the friends" from the tertianship in the Philippine.

1996. Von Armen beschenkt, Jesuiten, März 1996:14-15.

1998. Durch ihre Armut reich. Zur Armut im AT, Korrespondenz zur Spiritualität der Exerzitien 48, Heft 72:3-11.

1998. Vom Glück, Armen zu begegnen, Baustelle Theologie 1/2, S.3.

2003. How can the rich love the poor? OT suggestions for a present-day economy, in Religion, society and economics (eds. K. Pandikattu and A. Vonach, Frankfurt 2003:15-22). 